\title{
Eclesiastes 3,1-15 e Cecília Meireles: uma aproximação entre o tempo e a vida
}

\author{
Ecclesiastes and Cecilia Meireles: \\ an approach between time and life
}

Maria Cristina da Fonseca Elia

\section{Resumo}

A fugacidade do tempo e a brevidade da vida são temas clássicos, encontrados no âmbito da reflexão acerca da existência humana, tanto na vertente religiosa quanto filosófica, como também no âmbito da expressão literária. Este trabalho procura estabelecer um estudo comparativo, com foco literário, entre Eclesiastes 3,1-15 e alguns aspectos da poética de Cecília Meireles. Esta investigação está circunscrita à abordagem ora estilística ora temática, trazendo à luz a efemeridade da vida e a inquietação humana face ao tempo veloz.

Palavras-chave: Fugacidade do tempo. Brevidade da vida. Efemeridade. Vazio. Fruir a vida.

\section{Abstract}

The fleeting nature of time and the brevity of life are classical themes, found both within religious and philosophical reflections about human existence, as well as in literature. The present paper aims at stablishing a comparative study, from a literary point of view, between the Ecclesiastes 3,1-15 and some aspects of Cecília Meireles poetics. This investigation is circumscribed by an approach sometimes stylistic and sometimes thematic, which casts light upon the ephemeral aspect of life and human anxiety in the face of the fleeting nature of time.

Keywords: Fleeting nature of time. Brevity of life. Ephemerality. Void. Seizing life. 


\section{Introdução}

Esse artigo pretende fazer uma aproximação temática entre o texto Eclesiastes, capítulo 3, e alguns poemas de Cecília Meireles. Mais que o livro de Jó ou o Cântico dos Cânticos, o livro Eclesiastes, texto eminentemente profano, nos surpreende por sua presença no corpus bíblico. ${ }^{1}$

A perícope escolhida em Eclesiastes, 3,1-15, refere-se a um texto célebre não apenas no âmbito do Antigo Testamento (AT), mas também por ter transposto os limites das Sagradas Escrituras com sua temática tão humana e tão provocadora. Já nas primeiras frases do livro, o autor se apresenta como sábio, sob a identidade de Salomão (cf. Ecl 1,12); entretanto, ao contrário dos sábios do livro dos Provérbios, o sábio do Eclesiastes não transmite uma sabedoria tradicional. Descobriu que a felicidade é frágil, que os esforços para conquistá-la são inúteis e chega a se perguntar se a vida vale a pena ser vivida. Em sua investigação, o sábio percebe o efêmero e o incerto das alegrias da vida. A partir desse balanço negativo, o narrador conduz o leitor a reflexões sobre como levar a vida de forma a atenuar o sofrimento e a ficar bem tal como ela se apresenta.

Quanto aos textos-poema de Cecília Meireles, foram escolhidos alguns que, pelo lirismo transcendente e melodia suave, traduzem a melancolia, o silêncio e a solidão humana, traços pertencentes a uma corrente literária do Modernismo brasileiro, da qual Cecília Meireles foi grande intérprete. Essa pequena seleção de poemas, ainda que preservando sua especificidade literária e seu contexto histórico, ecoa e repercute de alguma forma a temática do Eclesiastes: a brevidade da vida, a fugacidade do tempo e a efêmera felicidade do ser humano. Isso desejamos mostrar.

Eclesiastes e Cecília Meireles: por um lado, a época dos Ptolomeus, século III aC, e por outro, o Modernismo Brasileiro, primeira metade do século XX. Que tipo de aproximações podemos encontrar? É o que se busca trazer nesse artigo ${ }^{2}$. Tratando-se de uma abordagem interdisciplinar envolvendo poemas profanos (o termo é aqui usado em oposição a sagrado) de uma determinada corrente literária e um texto bíblico - ainda que numa forma acentuadamente literária - inserido na revelação divina, a abordagem será de cunho literário, sob a égide do conceito de autonomia do texto literário.

\footnotetext{
${ }^{1}$ MANDEL, Y; NATAF, G. L’Ecclesiaste. Qohelet, le prédicateur désenchanté. Paris: Berg International, 2011, p. 7.

${ }^{2}$ Para as citações do texto Eclesiastes, será utilizada a Bíblia de Jerusalém, conforme indicado nas referências bibliográficas.
} 
Vem ao encontro dessa escolha um episódio relatado pelo autor Georges Nataf, cujo resumo é: convidado para participar de um congresso organizado pela Association catholique française pour l'étude de la Bible, Roland Barthes afirmou, face aos biblistas ali presentes, que, para a crítica literária, "o autor deve dar lugar ao leitor: o autor não é mais, assim, o fiador do sentido de sua obra"3.

Assim sendo, as aproximações e relações que aqui serão feitas terão em conta este princípio de autonomia do texto literário, principalmente no aspecto de sua recepção pelo leitor.

\section{Pressupostos teóricos aqui utilizados}

\subsection{Para a abordagem do texto Eclesiastes}

A linguagem utilizada no texto é um indício de datação. O Coélet está escrito em hebraico falado, popular. ${ }^{4}$ Usaremos, para as informações concernentes à datação, os ensinamentos de aula ${ }^{5}$ :

O texto apresenta numerosos aramaísmos (...) e dois termos persas (...). Há algumas ideias que encontram semelhança com o pensamento helenista (cf. 7,16-17) (...). Espelha-se no livro um conhecimento genérico, como poderia ter um judeu culto do século III, quando as ideias helenistas já eram de amplo domínio em todo Mediterrâneo. (...) Também meios técnicos citados (cf. 12,6) e a referência à "província" $(5,7)$ falam em favor dessa época. Além disso, testemunha é também o hebraico do livro, muito próximo ao da Mishnah. (...)

Com isso, a data mais aceita para o livro é a metade do século III (ca 250). ${ }^{6}$

Tardiamente incorporado ao cânon hebraico, lido na Festa dos Tabernáculos, o Eclesiastes foi copiosamente comentado, tanto pelos Sábios de Israel quanto pelos Padres da Igreja. $^{7}$

O Eclesiastes foi considerado o livro mais obscuro e sem equivalente na

\footnotetext{
${ }^{3}$ MANDEL, Y; NATAF, G. L'Ecclesiaste. Qohelet, le prédicateur désenchanté, p. 34.

${ }^{4}$ BUEHLMANN, A. "Coélet”. In: RÖMER, T; MACCHI, J.-D.; NIHAN, C. (Orgs). Antigo Testamento: história, escritura e teologia. São Paulo: Loyola, 2010, p. 657.

${ }^{5}$ Disciplina Escritos Sapienciais. Departamento Teologia, PUC-Rio, 2016.

${ }^{6}$ LIMA, M. L. C. Qohelet. Apostila de aula - Escritos Sapienciais. Dep. Teologia, PUC-Rio, 2016, p. 2.

${ }^{7}$ MANDEL, Y; NATAF, G. L’Ecclesiaste. Qohelet, le prédicateur désenchanté, p. 7.
} 
Bíblia em virtude de inúmeros de seus aspectos. Se diversas passagens são embaraçosas, restringem-se, todavia, a digressões e acessórios do texto, fato reconhecido por estudiosos do assunto. Contudo, o texto inscreve-se perfeitamente no contexto da revelação divina. Em seu conjunto, o livro é bem claro e sua filosofia geral bem simples. $\mathrm{O}$ autor repete com alguma insistência, às vezes fastidiosa - repetição essa que pertence à diegese da obra! -, que "tudo é vaidade", hébel (veleidade).

O termo hébel significa o que é inconstante e passageiro. A palavra "vaidade" não expressa esse significado com precisão, exceto no adjetivo "vão", pertencente à mesma família: "o termo unifica o livro, sendo nele usado por 38 vezes. No hebraico e no aramaico tardio tem o significado de sopro quente, vapor, fumaça, hálito (...). Hébel é o que é inútil, ineficaz."

O Eclesiastes também é conhecido por Coélet e em muitas ocasiões, neste trabalho, será usada essa denominação. A palavra "Coélet" vem do hebraico qahal. Esse termo, correspondendo ao grego ekklesia, igreja, ecclesia em latim, foi traduzido por Eclesiastes. ${ }^{9}$ Não é um nome próprio, e sim um substantivo comum usado às vezes com artigo; embora feminino em sua forma, constrói-se com o masculino. Conforme a explicação mais verossímil, é um nome de ofício e designa aquele que fala diante da assembleia.

O livro se compõe de uma sequência de parágrafos contendo, cada um deles, uma observação ou uma maneira de encarar a vida humana, cuja conclusão é sempre de uma frivolidade universal: tudo é vazio, "tudo é correr atrás do vento" (Ecl 1,1; 2,11; 2,24 dentre inúmeras outras citações). Para cada uma dessas conclusões parciais, o autor aponta experiências das mais diversas, que parecem todas convergir para o absurdo da vida. É difícil e arriscado sistematizar o pensamento do Coélet, muitos o consideram uma caderneta de notas esparsas.

O narrador, sob a identidade de Salomão, pretende ter conhecido todas as ocupações da vida (cf 2,1-10): a honra, a riqueza, o prazer, o poder, o luxo, o amor das mulheres e em tudo só ter encontrado a vacuidade, a veleidade, a inutilidade, a poeira. Como se não bastassem tantas desilusões, a ciência fatiga o espírito. Tudo é correr atrás do vento, é quimera, tolice, esforço inútil (cf. Ecl 1,14.17; 2,17 entre tantos outros textos similares).

Onde encontrar a paz em um mundo em que a moral recomenda o bem, mas no qual tudo encoraja e estimula ao mal? A sabedoria e a piedade não

\footnotetext{
${ }^{8}$ LIMA, M. L. C. Qohelet. Apostila de aula, nota 7, p. 4.

${ }^{9}$ MANDEL, Y; NATAF, G. L'Ecclesiaste. Qohelet, le prédicateur désenchanté, p. 7.
} 
são recompensadas, o pérfido recebe as honras devidas ao virtuoso, e esse encontra-se esmagado sob o peso dos infortúnios (cf. Ecl 2,15-16; 6,8; 8,14; $9,2)$. No interior da mais bela fruta, há um verme, tudo está corrompido. Muitos estudiosos veem no texto traços da literatura pessimista do Egito, com algumas notas do Canto do Harpista. ${ }^{10}$

Uma tal doutrina, no ambiente da Grécia antiga, e mesmo hoje em nossos dias, passaria sem dificuldade por materialista, pagã, ateia. Jamais poderíamos entendê-la saindo das mãos e da mente de um judeu piedoso do século III a.C. No entanto, o autor está longe de ser um infiel. Poderíamos ser tentados a julgá-lo cético, fatalista ou mesmo pessimista, sensibilizados por uma leitura mais ligeira e de superfície, mas jamais um infiel. É oportuno registrar que esses três adjetivos acima aplicados ao Coélet constituem objeto de muito debate ainda hoje entre estudiosos e exegetas desse texto. Mas se por um momento esse aspecto "incrédulo" possa emergir aos olhos de alguns, é inegável que o narrador não é nem ateu nem infiel, pois ele percebe Deus imenso, grande; um Deus que mostra seu infinito poder criando incessantemente a vida; e percebe o homem aterradoramente pequeno, mesquinho e impotente. Os desígnios de Deus são impenetráveis. Como a eles não se curvar?

Trata-se de um livro realista sobre a condição da Palestina, então colônia do império grego dos Ptolomeus, ao qual o povo devia pagar pesados tributos. "Coélet é um rico em confronto com problemas da aristocracia hierosolimita do séc III a.C." 11 Fazendo parte da elite intelectual de seu tempo, não há razão para duvidar que ele tenha conhecido os filósofos gregos; bem ao contrário, Coélet "representa o casamento judaísmo-helenismo (...) e avalia constantemente o pensamento tradicional à luz do pensamento grego" 12 .

O Coélet exprime a dupla exclusão política e econômica: "seu pessimismo reflete a frustração do aristocrata excluído das decisões políticas; por outro lado, e precisamente por falta de uma ocupação de responsabilidade, Coélet teve tempo e dinheiro para filosofar como cético." ${ }^{13} \mathrm{E}$, à diferença do que ocorre nos livros dos profetas e dos salmos, o narrador não se escandaliza com

\footnotetext{
${ }^{10}$ Cf. MANDEL, Y; NATAF, G. L'Ecclesiaste. Qohelet, le prédicateur désenchanté, p. 8.

${ }^{11}$ BUEHLMANN, A. "Coélet”. In: RÖMER, T; MACCHI, J.-D.; NIHAN, C. (Orgs). Antigo Testamento: história, escritura e teologia, p. 657.

${ }^{12}$ Ibidem, p. 659.

${ }^{13}$ KNAUF apud BUEHLMANN, A. "Coélet". In: RÖMER, T; MACCHI, J.-D.; NIHAN, C. (Orgs). Antigo Testamento: história, escritura e teologia, p. 658. "Cético" aqui utilizado com a ressalva mencionada na página anterior.
} 
o fato de existirem injustiças gritantes sob o sol, ao contrário, serve-se dessa clivagem para ilustrar o absurdo do mundo.

O "eu” do enunciador aparece logo em Ecl 1,12: "Eu, Coélet (...)”, "coloquei", "examinei" e prossegue por todo o texto em formas verbais na primeira pessoa singular, bem como no uso de elementos linguísticos referidos a essa pessoa do discurso: "disse em mim mesmo" (cf. 2,15); "eis o que observo" (cf. 5,17); "pesquisei e nada concluí" (cf. 7,29).

Esse "eu" enunciador permite transmitir conteúdos representados no interior da consciência. Tal diálogo consigo mesmo, em que o enunciador é, ao mesmo tempo, o destinatário "tu", está talvez na base de certas obscuridades do texto concernentes à fonte enunciativa, conforme adverte Buehlmann, em seu já citado capítulo. No entanto, a prudência recomenda não fazer afirmações simplistas, apressadas e categóricas. A esse respeito, ouçamos mais uma vez Alain Buehlmann: "a presença, no interior do discurso do Coélet, de enunciadores que parecem pressupor outros enunciadores, constitui uma das maiores dificuldades da interpretação." ${ }^{14}$

A polifonia do texto desenha uma constelação de enunciados generalizantes, "o pensamento vai e vem, corrige-se, não há um plano definido: mas trata-se de variações sobre tema único, a vaidade das coisas humanas"15. O objetivo desse pequeno livro é refletir sobre o vazio de uma vida cujo sentido escapa à mais rigorosa reflexão.

Em sua angustiante busca, o "eu" pessoal, individual e ao mesmo tempo coletivo e universal do narrador se depara com um problema que é de ordem epistemológica - o que posso saber e como? - e ainda nos lembra bem oportunamente Buehlmann, no mesmo capítulo ${ }^{16}$, que, na tradição bíblica, Coélet é o primeiro a introduzir o empirismo, a experiência vivida e observada, como critério de verdade. O pequeno livro é, sem dúvida, uma deliciosa fantasia filosófica.

\subsection{Para a abordagem do Movimento Modernista e Cecília Meireles}

Tristão de Ataíde propõe três fases para o Modernismo Brasileiro: a pri-

\footnotetext{
${ }^{14}$ BUEHLMANN, A. "Coélet”. In: RÖMER, T; MACCHI, J.-D.; NIHAN, C. (Orgs). Antigo Testamento: história, escritura e teologia, p. 659.

${ }^{15}$ BÍBLIA de Jerusalém. São Paulo: Paulus, 2002, p. 1070.

${ }^{16}$ BUEHLMANN, A. "Coélet”. In: RÖMER, T; MACCHI, J.-D.; NIHAN, C. (Orgs). Antigo Testamento: história, escritura e teologia, p. 660.
} 
meira é a da ruptura, ou, segundo sua expressão, a fase da piada, iniciada na célebre Semana de Arte Moderna de 1922, realizada no teatro Municipal de São Paulo, em fevereiro daquele ano, e que vai até 1930. A segunda fase vai de 1930 a 1945, e a terceira, de 1945 em diante, denominada pelo autor de Neomodernismo ${ }^{17}$.

Por volta de 1925, o Modernismo se divide em grupos e dentre eles está a corrente espiritualista - também conhecida como totalista, por abranger o conflito entre o mundo material e espiritual - à qual pertence Cecília Meireles. Esse grupo se formou em torno da revista Festa.

Mário de Andrade, vinte anos após a trovoada de 1922, traça o rumo básico do movimento modernista: por um lado destruição do espírito conservador e reformista, demolindo tabus e preconceitos; e por outro lado permanente busca de pesquisa estética, de atualização da inteligência artística brasileira e estabilização de uma consciência criadora nacional. Reconhece, ele, que os objetivos visados foram atingidos. ${ }^{18} \mathrm{~A}$ ideia central da Semana de Arte Moderna de 1922 foi a de destruir e fazer escândalo, com aguçado sentido crítico.

\subsection{O absurdo da condição humana}

O sentimento de mal-estar que o ser humano experimenta face à existência pode surgir do automatismo monótono e repetitivo de nossas ações, da hostilidade do mundo (da natureza e da sociedade), da constatação que levamos uma vida nada radiosa e opaca. Além de tudo - e talvez principalmente - todo esse mal-estar existencial se inscreve na temporalidade: o tempo conduz tudo ao aniquilamento e à morte. $\mathrm{E}$ a morte iguala tudo, o sensato e o insensato, o justo e o ímpio. Face a esse cenário sem lógica ou racionalidade, o ser humano experimenta desolação e tormento.

Pode-se compreender este sentimento como o confronto entre a fragilidade da existência e um profundo desejo de absoluto que habita o homem. Deus plantou no fundo do ser humano o sentido da eternidade, o homem é o único ser que reflete sobre sua origem e seu destino. Sabe, intuitivamente, que algo ultrapassa sua situação imediata, que deve haver uma transcendência. E o Coélet descobriu que tudo na vida do homem é transitório e acidental. Num

${ }^{17}$ Cf. COUTINHO, A. “A Revolução Modernista no Brasil”. In: COUTINHO, A. Introdução à Literatura no Brasil. Rio de Janeiro: Livraria São José, 1959, p. 297.

${ }^{18}$ M. de Andrade, apud COUTINHO, A. “A Revolução Modernista no Brasil”. In: COUTINHO, A. Introdução à Literatura no Brasil, p. 289. 
mundo assim "organizado", o homem atravessa uma existência injustificada e tem consciência que aquele intenso desejo de absoluto que ecoa no mais profundo de seu ser dá lugar ao vazio, à veleidade, ao irracional, tudo é vão, tudo é inútil e sem sentido. E ele, o homem, com sua sede de absoluto, não passa de um mesquinho autômato. Dessa antinomia, nasce o sentimento de absurdo da vida: resta ao homem a vida limitada, relativa, transitória.

Vimos que o sábio do Eclesiastes, em sua investigação, descobre que essa vida pode ser agradável (cf. 3,12) Mas como desfrutar de um mundo transitório e contingente, no qual o dinamismo das mudanças da physis está sujeito ao tempo? (cf. 7,25)

Parece-nos ouvir o sábio do Eclesiastes responder: vivendo no momento, na parte, nesse tempo fugidio que flui sem cessar. Assim fazendo, esse momento presente, um mero fragmento de tempo, frágil e efêmero, se torna experiência de eternidade. Este processo se realiza pouco a pouco, nos momentos que se sucedem. É uma tentativa humana de saciar a sede de plenitude, de absoluto, de eternidade que Deus pôs no coração do homem, dotando-o do sentido do eterno. Parece-nos que o que sabemos é pouca coisa ao lado do que existe. Algo nos diz que temos sob os olhos apenas um episódio do drama imenso que se chama história. Para além de nossa esfera, passam-se coisas que nossa linguagem terrena não é capaz de exprimir.

\section{Coélet: estudo da perícope 3,1-15}

\subsection{Análise do texto em tela}

A perícope em tela vem precedida de uma exposição de motivos: o narrador declara que vai explorar todas as possibilidades de prazer e gozo debaixo do sol (Cf. 1,12; 2,11), para tentar encontrar alguma resposta que permita escapar da constatação das primeiras linhas do prólogo: vazio dos vazios ${ }^{19}$ “(...) que proveito tira o homem de todo trabalho com que se afadiga debaixo do sol?" (1,2-3)

A expressão "debaixo do sol" - que se repetirá 24 vezes em todo o livro ${ }^{20}$ - é importante para delimitar, obsessivamente, o alcance da pesquisa do sábio: os limites da terra. E então vem a pergunta que o angustia: qual o benefício de uma vida terrestre se limitada ao horizonte da terra?

\footnotetext{
${ }^{19}$ A Bíblia de Jerusalém usa a expressão "vaidade".

${ }^{20}$ Cf. STEINMANN, J. Ainsi parlait Qohelet. Col. Lire la Bible, n. 38. Paris: Cerf, 1973, p. 34.
} 
Que espetáculo sob o sol vê Coélet? A monotonia da vida: ao movimento das gerações humanas que se sucedem, opõe-se a permanência imóvel da terra, sobre a qual o sol lança, de oriente a ocidente, sua luz sempre idêntica. E nada há de novo, constata Coélet, a vida humana não traz nenhuma surpresa, senão o vai e vem monótono do vento, do sol, dos rios.

Essa exposição de motivos pela busca de um sentido para a vida terrena é expandida ao paroxismo de uma embriaguês lúcida, e o sábio conclui que tudo é vão, inútil, tolice. Após esse contexto de indagações e de respostas vãs para o sentido da vida se situa a perícope de nosso estudo.

A perícope se compõe de 15 versículos, escritos de forma concisa, ricos em imagens evocadoras. Ela se constitui em uma unidade literária, não apenas em sua delimitação tipográfica, visual, com contornos bem nítidos em relação à totalidade do texto, mas também por apresentar uma unidade temática que evoca a condição humana conduzida na fluidez do tempo.

Do versículo 1 ao 8, o texto se apresenta sob a forma de uma monótona, porém poética e lírica, litania. Esse efeito é obtido pela repetição 28 vezes da estrutura tempo de + verbo no infinitivo, estrutura essa que se organiza, por sua vez, em grupos, polarizando os infinitivos 2 a 2, como em: tempo de nascer $x$ tempo de morrer; tempo de chorar $x$ tempo de rir. Temos assim, em outras palavras, 14 vezes a anáfora de contrastes: gemer/bailar, buscar/perder, rasgar/ costurar, calar/falar etc. Essa construção anafórica, que domina toda a primeira parte da perícope, contribui para criar esse tom de litania e traduz o eterno vai e vem da vida humana, sendo o homem obrigado a diferentes momentos de atividades contraditórias.

Os 14 pares de antíteses evocam extremos que circunscrevem pequenas totalidades delimitadoras do homem sem lhe oferecer nenhuma saída de escape: nascer/morrer,; plantar/arrancar, matar/curar (...) chorar/rir (...) buscar/ perder (...) guerra/paz. O último par, diferente de toda sequência, opõe dois substantivos. Recorrendo a Ravasi, podemos interpretar sob a mística das cifras, cara ao Oriente, "um resultado de 28 elementos que podem ser decompostos em 2 totalidades simbólicas, o 7 da plenitude e o 4 dos pontos cardeais, plenitude de espaço" "21. Ou a totalidade de (7x2) polaridades, recobrindo "as estações humanas".

A segunda parte da perícope, (v.9 ao 15) traz as conclusões do sábio, que observa a "tarefa que Deus deu aos homens para que delas se ocupem" (v.10)

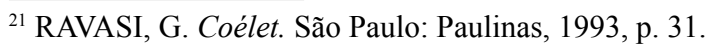


e conclui no v.15: "o que existe, já havia existido; o que existirá, já existe, e Deus procura o que desapareceu". Deus é a causa primeira e última, a causa suprema que dá sentido e plenifica a existência humana "debaixo do sol". Se o sábio não compreende a sucessão interminável e contraditória dos atos da vida, sabe, por outro lado, que a origem e o fim último da vida ultrapassam os limites circunscritos "sob o sol"; se ignora os desígnios de Deus para o homem, sabe que eles existem; sabe que a obra de Deus é perfeita (cf. v.14) e que "Deus assim faz para que o temam" (v.14). A perícope em estudo opõe a perenidade da criação aos tempos limitados da ação humana. Coélet agora "repropõe sua tese circular e reiterativa (...) abraçando passado-presentefuturo (...) ; Deus é o grande motor imóvel dessa constante retomada (...)". ${ }^{22}$

\subsection{Alguns temas afins}

\section{O tempo}

O sábio começa o capítulo 3 estabelecendo que a existência humana, "sob o céu", é uma sucessão de atividades concretas em contraste, ações opostas que se anulam, e cada uma delas tem seu tempo-instante, e cada tempo tem seu valor. Nesse incessante balanço, sábio será aquele que souber aproveitar do momento oportuno, pois o homem dispõe apenas do momento presente para agir, e este momento é fugidio; conhecendo a morte, o homem deve ver a vida como dom; a felicidade é reconhecer tais dons e vivê-los plenamente. ${ }^{23}$

A descoberta fundamental do Coélet é o transitório, nada é para sempre, e tudo é vão, vazio, inútil (hébel). O homem está esvaziado de transcendência, é um mero homo faber. Resta-lhe a vida limitada, relativa, transitória, mas muito agradável. ${ }^{24}$

Como desfrutar de um mundo transitório e contingente? A resposta do sábio é: no momento presente, na parte, no fragmento, no comer e beber, no abraçar e separar, no rir e chorar, no gemer e bailar... tudo flui. O enunciado de 2,24-26 será ilustrado em 3,1-8, que apresenta uma sucessão de contrastes, em construção ritmada, marcada por versos curtos. A repetição anafórica da palavra "tempo" bem como da estrutura tempo + verbo de ação - com uma única

\footnotetext{
${ }^{22}$ RAVASI, G. Coélet, p. 115.

${ }^{23}$ Ibidem, p. 99.

${ }^{24}$ Cf. BUEHLMANN, A. “Coélet”. In: RÖMER, T; MACCHI, J.-D.; NIHAN, C. (Orgs). Antigo Testamento: história, escritura e teologia, p.660.
} 
exceção - cria importante efeito de sentido de musicalidade e cadência, sublinhando o ritmo acelerado da existência e a inexorável passagem do tempo.

Os versículos 3,1-8 descrevem o retorno regular dos fenômenos da criação, sujeitos ao dinamismo da physis. Tudo tem sua estação. Essas antíteses não estão no texto para falar do imprevisível destino do homem, mas para proclamar a indiscutível soberania de Deus, senhor do tempo $(8,6)$ : chorar e gemer quando Deus lhe dá uma aflição; rir, cantar e bailar quando lhe permite o júbilo; combater no calor da batalha, depois curar as feridas; acumular na prosperidade, desapegar-se quando é momento de sacrifício. Submeter-se à vontade de Deus e não querer mudar o que é imutável (v.14). Ter uma visão clara de uma verdade não impede ao Coélet de ver também, logo em seguida, a verdade contrária com a mesma clareza.

A tarefa do homem é seguir na perspectiva da providência (v.10) porque tudo o que Deus fez é bom (v.11). O homem deve desfrutar dos bens advindos do seu trabalho (v.12), conformar-se com a vontade de Deus no tempo presente, pois é no momento presente que se dá a relação do homem com o Criador. Quando olhamos para a criação como dádiva de Deus tudo ganha outro colorido. $\mathrm{O}$ encontro com Deus está no momento que foge, no aqui e agora. $\mathrm{O}$ resto é saudade ou preocupação.

No Coélet, fala um judeu consequente que reconhece a grandeza do Deus que perpetuamente cria a vida, e cujos desígnios são impenetráveis. Como não se inclinar diante do poder de Deus? O homem prudente e sensato teme a Deus, esta é a lição do Eclesiastes. Tudo é dom de Deus $(3,13)$, mas o espírito limitado do homem não pode ainda contemplar o plano divino em seu conjunto, tão somente acomoda-se ao que lhe é paulatinamente desvelado $(3,11)$; deve, pois, temer a Deus, e nele confiar. ${ }^{25}$

Que proveito tira o homem de seu trabalho $(3,9)$ se tudo obedece a uma vontade superior à sua? Este versículo retoma a questão de 1,3 e a resposta do sábio começa em 3,10: "observo" e "compreendi”, usando a observação da vida cotidiana, numa investigação empírica face à realidade, percebe que a natureza é a própria injustiça e a sociedade tecida de erros e violações da justiça. Nem por isso o sábio estabelece dogmas, propõe catecismos religiosos, evoca sacerdotes, doutores ou profetas. Temer a Deus é tudo, e em meio à fluidez das coisas do mundo, voltemo-nos para o Criador.

\footnotetext{
${ }^{25}$ Como nos lembra São Paulo em Rm 8,28: "Tudo concorre para o bem de quem ama a Deus".
} 
Deus plantou, no fundo do ser humano, o sentido da eternidade. O homem é o único ser que reflete sobre sua origem e destino. Intuitivamente, sabe que algo ultrapassa sua situação imediata e contingente, pressente uma transcendência. Algo lhe diz que tem sob os olhos apenas um episódio do drama imenso que se chama história. Para além de nossa esfera, passam-se coisas que nossa linguagem terrena não é capaz de exprimir. Contudo, as expressões artísticas, e dentre elas a literatura, procuram traduzir essa busca pelo absoluto, pelo eterno, cuja semente Deus plantou no coração do homem.

$\mathrm{Na}$ perspectiva do Coélet, o momento presente se torna experiência de busca de algo perene. Ao contrário do homem moderno, o narrador do Coélet não possui ainda o conceito de eternidade, e por essa razão seu entendimento não vai nessa direção. Entretanto, percebe a necessidade de que haja algo que ultrapasse o temporal, embora ainda não detenha as categorias teológicas para responder a este seu anseio. Desfrutar do que Deus dá, a cada momento, de acordo com seus desígnios, é uma forma de saciar esta sede.

Ora, quando o Coélet se refere à monótona circularidade da vida "sob o sol", ele entende haver algo sobre o sol, um além daquilo que se vê no mundo físico e visível. As impenetráveis obscuridades do governo do mundo se dissipariam, aos olhos do sábio, se no texto entrasse a noção de vida além da morte. Mas para ele, a vida termina com a morte, que é a mesma para o homem e para o animal. A morte leva ao sheol, a uma vida de apagamento. Ele sente necessidade que haja "algo mais", porém a fé judaica da época não lhe permite dar uma resposta a esse seu anseio. Daí sua conclusão que tudo é vazio, sem sentido, ou seja: "correr atrás do vento".

\section{Criação, pecado e revelação}

No texto do Eclesiastes, a criatura, em meio à criação, que é bela, evoca o transitório, a finitude e a morte. A apresentação do mundo em 1,4-11 "não fala de Deus, mas apenas dos elementos do mundo e do homem"26. No Gênesis, de acordo com o texto bíblico, o primeiro homem, ao ser introduzido no mundo, não tinha conhecimento do bem e do mal, foi posto em perfeita harmonia em

\footnotetext{
${ }^{26}$ BUEHLMANN, A. "Coélet”. In: RÖMER, T; MACCHI, J.-D.; NIHAN, C. (Orgs). Antigo Testamento: história, escritura e teologia, p. 660.
} 
meio à criação dela desfrutando em plenitude, porém decaiu para uma vida cheia de tormentos, de obstáculos e trabalho penoso (cf. Gn 3,19).

O capítulo 3, onde se situa a perícope, opõe a perenidade da criação aos tempos limitados da ação humana, fluida e fragmentada. O sábio descobre que o mundo eterno e belo existe sem a ação do homem e funciona sem ela. Trata-se de uma formulação racionalista e empírica do relato da criação.

A este homem que, contudo, teme a Deus, falta a resposta última para o sentido da vida e o além da morte, o que o colocaria em relação com a transcendência. Este homem se encontra diante de uma porta fechada para além da qual existe um segredo que somente a revelação pode desvelar, pois ele tem fé e aceita a revelação.

\section{Cecilia Meireles}

\subsection{Alguns dados biográficos ${ }^{27}$}

Cecília Meireles nasceu em 7 de novembro de 1901, no Rio de Janeiro, e faleceu em 9 de novembro de 1964. Teve a infância marcada pela morte dos pais e de outros familiares, inclusive irmãos, o que provavelmente deu-lhe o sentimento da brevidade da vida, tema constante em seu lirismo.

Órfã muito cedo, soube ainda de várias mortes ocorridas na família, fato que ela traduziu de forma bastante original: "À casa de minha avó chegavam continuamente malas de gente da minha família que ia faltando. E eu, muitas vezes, em vez de conhecê-las em seus lugares, vi-as saindo de malas." ${ }^{28}$ Soube também transformar as marcas da solidão em manancial de sua inspiração lírica, como ela própria declara: "Minha infância de menina sozinha deu-me duas coisas que parecem negativas, e foram sempre positivas para mim: silêncio e solidão." 29

São dela ainda as palavras: "A noção de transitoriedade de tudo é o fundamento mesmo da minha personalidade. Creio que isso explica tudo quanto tenho feito, em Literatura, Jornalismo, Educação e mesmo Folclore." ${ }^{30}$

\footnotetext{
${ }^{27}$ Informações da biografia de Cecília Meireles colhidas em AZEVEDO FILHO, L. A. Poesia e Estilo de Cecília Meireles. Rio de Janeiro: José Olympio, 1970, pp. 8-12.

${ }^{28}$ AZEVEDO FILHO, L. A. Poesia e Estilo de Cecília Meireles, p. 13.

${ }^{29}$ Ibidem, p. 8.

${ }^{30}$ Ibidem, p. 13.
} 
Além dos volumes de poesia, Cecília Meireles publicou vários ensaios, conferências, estudos folclóricos, peças de teatro, traduções, artigos e composições musicais. Seus poemas foram traduzidos para o francês, espanhol, italiano, inglês, alemão e húngaro.

\subsection{Traços de seu lirismo}

Nas palavras de Mário da Silva Brito, a poesia de Cecília Meireles é "intemporal, diáfana e cristalina e, além de nobre e discreta, delicada e dotada de musicalidade que lhe acentua a beleza" ${ }^{31}$. E Mário de Andrade afirma: "Jamais a poesia nacional alcançou tamanha evanescência, tanto verbal como psíquica." 32

Cecília Meireles viveu em ambiente de espiritualidade e misticismo, e sua lírica revela traços de natureza barroca decorrentes do conflito entre corpo e alma, vencendo sempre o espírito. Uma poesia reconhecidamente marcada pela musicalidade. Alguns de seus livros trazem títulos com claras referências musicais: Baladas para El-Rei (1925), Vaga Música (1942), Canções (1956). A musicalidade de suas composições líricas é um fator favorável ao recolhimento e introspecção, criando uma atmosfera de autocontemplação espiritual em busca de transcendência.

$\mathrm{Na}$ literatura brasileira modernista, Cecília Meireles ocupa um lugar à parte, pois se afasta das buscas nacionalistas - como por exemplo as temáticas regionalistas - em favor de um lirismo musical que transforma em belos poemas sua melancolia, a saudade e o tempo que tudo devora.

\subsection{Escolha do corpus lírico}

Para este trabalho, foram selecionadas sete composições líricas de Cecília Meireles, tomando por critério o fato de haver aproximações temáticas entre esses poemas e o texto do Coélet: a) Do livro Viagem, Lisboa, Editora Império, 193933, os poemas: "Motivo", "Retrato", "Epigrama n²" e "Asso-

\footnotetext{
${ }^{31}$ BRITO, M. S. Poesia do Modernismo. Rio de Janeiro: Civilização Brasileira, 1968, p. 170.

${ }^{32}$ Mário de Andrade apud BRITO, M. S. op. cit., loc. cit.

${ }^{33}$ O livro Viagem foi premiado pela Academia Brasileira de Letras em 1938 - e recebeu, inclusive, elogio de Mário de Andrade: "Cecília Meireles está em grande plenitude de sua arte. Com Viagem ela se afirma entre os maiores poetas nacionais". Mário de Andrade apud AZEVEDO FILHO, L. A. Poesia e Estilo de Cecília Meireles, p. 32.
} 
vio"; b) De Vaga Música, Editora Pongetti, 1942, "Em Voz Baixa" e "Lua Adversa"; c) De Mar Absoluto, Porto Alegre, Editora Globo, 1945, "4 Motivo da Rosa". A seguir faremos uma apreciação temática dessas poesias em sua "relação de eco" com o Eclesiastes.

\section{Motivo}

Eu canto porque o instante existe / e a minha vida está completa.

Não sou alegre nem sou triste: / sou poeta.

Irmão das coisas fugidias, / não sinto gozo nem tormento. / Atravesso noites e dias / no vento.

Se desmorono ou se edifico, / se permaneço ou me desfaço, / - não sei, não sei.

Não sei se fico / ou passo.

Sei que canto. E a canção é tudo. / Tem sangue eterno a asa ritmada.

E um dia sei que estarei mudo; / - mais nada.

Nesse poema se concentram várias constantes temáticas de Cecília Meireles, revelando os "motivos" de sua poesia. "Eu canto porque o instante existe", indica o desejo de valorização subjetiva e momentânea de cada hora de sua vida.

Outro tema constante é o sentimento aflitivo da fugacidade do tempo (“coisas fugidias") e da brevidade da vida, a única certeza é que tudo acabará: "um dia sei que estarei mudo; - mais nada."

O verso "não sinto gozo nem tormento" traduz a indiferença diante da existência, bem como toda a terceira estrofe que condensa o ciclo da vida feito de vida/morte, fazer/desfazer, ser/não ser, tal como já afirmado no Eclesiastes.

A metáfora que relaciona a poesia (a "canção") a uma "asa ritmada" exprime que também o poema é transitório em seu voo ("asa") para a espiritualidade.

Observe-se ainda o corte do verso longo, procedimento estilístico que tem por efeito colocar em evidência as últimas palavras de cada estrofe que remetem às temáticas: "sou poeta"; "no vento", que é coisa fugidia; "ou passo", que se opõe à permanência; "mais nada", que traduz, em última instância, uma aflitiva aspiração ao infinito, ao absoluto, à transcendência. 


\section{Retrato}

Eu não tinha este rosto de hoje, / assim calmo, assim triste, assim magro, nem estes olhos tão vazios, / nem o lábio amargo.

Eu não tinha estas mãos sem força, / tão paradas e frias e mortas; eu não tinha este coração / que nem se mostra.

Eu não dei por esta mudança, / tão simples, tão certa, tão fácil:

- Em que espelho ficou perdida / a minha face?

A fugacidade do tempo e o desencanto face à brevidade da vida estão condensados neste poema. As duas primeiras estrofes começam com o verbo no imperfeito do indicativo e na forma negativa exprimindo o que era e não é mais: "eu não tinha (....)". Ao fazer o retrato do tempo presente, esse tempo verbal tem valorização negativa pois seu rosto de hoje é triste, magro, seus olhos são vazios e seu lábio amargo; as mãos sem força, paradas frias e mortas - observar a progressão dos adjetivos culminando com a não vida.

A repetição anafórica "eu não tinha" + parte do corpo três vezes no início de cada estrofe, com ligeira modificação na terceira, que substitui a parte do corpo (rosto, mãos) pela síntese "mudança", enfim, essas anáforas, reiterações monótonas, criam um ritmo de litania que exprime o cansaço de dias tristes. Como não associar este efeito de "litania monótona" à nossa perícope $3,1-15$, também construída em sequência de anáforas, conforme já assinalado?

$\mathrm{Na}$ última estrofe, a perplexa indagação diante da inexorável - "tão certa" - passagem do tempo, que a poeta não percebeu nos seus belos dias: "Em que espelho ficou perdida a minha face?"

\section{Epigrama $\mathrm{n}^{\mathrm{0}} 2$}

És precária e veloz, Felicidade. / Custas a vir, e, quando vens, não te demoras.

Foste tu que ensinastes aos homens que havia tempo, / e, para te medir, se inventaram as horas.

Felicidade, és coisa estranha e dolorosa. / Fizeste para sempre a vida ficar triste:

porque um dia se vê que as horas passam, / e um tempo, despovoado e profundo persiste. 
Neste poema, que traz no título a palavra "epigrama", que pode significar farsa, sátira, farpa, Cecília Meireles traz, numa fórmula mordaz, sua definição de felicidade, que nasce da profunda consciência da fugacidade do tempo. Todo poema é para dizer, em resumo, que a felicidade não existe porque o tempo voa. Cecília Meireles personifica a felicidade e se dirige a ela em tom acusatório: "foste tu que ensinaste aos homens que havia tempo e, para te medir, se inventaram as horas" e um dia "se vê que as horas todas passam, e um tempo, despovoado e profundo, persiste".

O pessimismo está, igualmente, presente na adjetivação para a felicidade: veloz, precária, que custa a vir (correspondendo a: se faz esperar, mas o tempo passa para o ser humano...), estranha, dolorosa e causadora da tristeza. E para o tempo: despovoado e profundo. As antíteses, bem ao gosto barroco: a felicidade traz a tristeza; o tempo despovoado persiste, a felicidade é veloz.

Considero que esta composição, bem como " $4^{\circ}$ Motivo da Rosa" - que veremos adiante em Mar Absoluto - concentram de forma intensa a temática da perícope do Eclesiastes aqui estudada, ao passo que o poema anterior remete à mesma perícope no aspecto estrutural.

Assovio

Ninguém abra a sua porta / para ver que aconteceu:

saímos de braço dado, / a noite escura mais eu.

Ela não sabe o meu rumo, / eu não lhe pergunto o seu:

não posso perder mais nada, / se o que houve já se perdeu.

Vou pelo braço da noite, / levando tudo que é meu:

- a dor que os homens me deram, / e a canção que Deus me deu.

Nesse poema destacamos a musicalidade sempre presente, herança do simbolismo, preconizada por Verlaine - "de la musique avant toute chose, et pour cela préfère l'impair" ${ }^{\prime 3}$, - que revela ao postulante à poesia um crucial segredo da arte poética. Aqui temos, em Assovio, um exemplo disso: metro de 7 sílabas.

O poema constrói uma atmosfera de sombria solidão, ansiedade mística

\footnotetext{
${ }^{34}$ Trad. livre nossa: "música antes de tudo, e para isso preferir o verso ímpar". VERLAINE, Paul. "Art Poétique”. In: LAGARDE, A.; MICHARD, L. Collection Littéraire XIXe. Siècle. Paris: Bordas, 1962, p. 510.
} 
e penumbra, dentro da qual a subjetividade da poeta busca, acompanhada pela canção que Deus [lhe] deu, a consolação do além, da transcendência. Observe-se a humanização da noite, que lhe dá o braço, exprimindo a integração do homem com a natureza, ao passo que junto à humanidade a poeta encontrou incompreensão e "a dor que os homens [lhe] deram".

Em voz baixa

Sempre que me vou embora / é com silêncio maior. / As solidões deste mundo / conheço-as todas de cor.

Desse-me a sorte um cavalo, / Ou um barco em cima do mar!

Relincho ou marulho - alguma / coisa que me acompanhar!

Mas não. Sempre mais comigo / vou levando os passos meus, até me perder de todo / no indeterminado Deus.

$\mathrm{Na}$ "asa ritmada" desse poema pleno de musicalidade - segundo conselho de Verlaine, temos, outra vez, um metro ímpar de 7 sílabas - figuram os temas secundários da fugacidade do tempo, solidão, renúncia, indiferença e desencanto que circunscrevem uma cosmovisão angustiante, dentro da qual está presente a busca pelo transcendente, o eterno "até me perder de todo / no indeterminado Deus". Cecília Meireles "busca permanentemente o sentido último da existência, sem encontrá-lo nesse dualismo conflitual entre a terra e o céu." ${ }^{35}$

Lua adversa

Tenho fases, como a lua. / Fases de andar escondida, / fases de vir para a rua...

Perdição da minha vida! / Tenho fases de ser tua, / tenho outras de ser sozinha.

Fases que vão e que vêm, / no secreto calendário / que um astrólogo arbitrário / inventou para meu uso.

E roda a melancolia / seu interminável fuso!

Não me encontro com ninguém / (tenho fases, como a lua...)

No dia de alguém ser meu / não é dia de eu ser sua... E, quando chega esse dia, / o outro desapareceu...

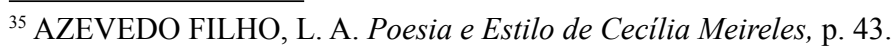


A procura inútil do sentido da existência retorna com a metáfora da lua - cíclica em suas fases e circularidade adversa - num tom de confidência em musicalidade fugidia. Em "Lua Adversa", Cecília Meireles traduz, mais uma vez, "sua angústia metafísica e sua marcha estética em busca dos caminhos da eternidade (...)". ${ }^{36}$

\section{$4^{\circ}$ Motivo da Rosa}

Não te aflijas com a pétala que voa: / também é ser, deixar de ser assim.

Rosas verás, só de cinzas franzida, / mortas, intactas pelo teu jardim.

Eu deixo aroma até nos meus espinhos / ao longe, o vento vai falando de $\operatorname{mim}$.

E por perder-me é que vão me lembrando, / por desfolhar-me é que não tenho fim.

$\mathrm{Na}$ expressão desencantada da fugacidade do tempo e do efêmero que há em sua poesia, Cecília Meireles busca a espiritualidade, o eterno, o perene; em outras palavras: o que não seja efêmero.

Partindo do tema central "também é ser deixar de ser assim", Cecília Meireles desenvolve-o, aceleradamente, na cadência de seus versos, "asa ritmada", pois célere é o passar do tempo, em busca de uma essência profunda, da perenidade, do eterno: "é por desfolhar-me que não tenho fim". O leitmotiv de sua poesia, que é a procura de Deus, ajusta-se bem às imagens da temática do tempo. ${ }^{37}$

\section{Considerações finais}

O tempo tem papel crucial nos dois corpora aqui analisados, pois em torno do transitório e da fugacidade dos instantes se constrói, no Eclesiastes e em Cecília Meireles, a temática da brevidade da vida e do efêmero da condição humana, bem como o tema do sentimento do absurdo da existência e do apelo do absurdo.

No contexto do Eclesiastes, o que resta ao homem sensato é o temor a Deus $(\operatorname{cf} 12,13)$. A chave da interpretação é perceber que o autor se põe

\footnotetext{
${ }^{36}$ AZEVEDO FILHO, L. A. Poesia e Estilo de Cecília Meireles, p. 63.

${ }^{37}$ Cf. ibidem, p.70.
} 
na perspectiva do leitor para conduzi-lo a uma reflexão sobre a falta de sentido da vida e do mundo, a fim de levá-lo a Deus. Por um lado, o desencanto, a indiferença e perplexidade face às coisas terrenas. Tudo sob o sol é transitório, efêmero, e sendo assim todo esforço do homem é insensatez. Por outro lado, a certeza de que o único recurso do homem está no temor a Deus (cf.12,13). Um fio condutor pessimista atravessa a trama identificado com o vazio, a futilidade, a veleidade. É preciso remover todas as falsas seguranças e ilusões, desprezar as futilidades para se alçar à contemplação do absoluto.

Coélet percebe que, na vida do homem, tudo está determinado e ao morrer vai para o sheol, onde não há consciência, amor, comunicação nem entre os homens e Deus, nem entre as pessoas. Se o homem é passageiro, o mundo e sua história - os "tempos" - continuam. Face a essa realidade para a qual o sábio não encontra solução, resta ao homem aproveitar do tempo presente, do tempo favorável.

Coélet ignora a possibilidade do julgamento divino após a morte, mas ele percebe talvez haver aí uma falta, uma ausência, está faltando algo que explique e plenifique a vida. $\mathrm{O}$ sábio sofre grande desapontamento. Somente com a ideia de ressurreição dos mortos - com os autores apocalípticos - se poderá resgatar a sabedoria humana do niilismo. ${ }^{38}$

É interessante notar que o texto começa pela conclusão, "vazio dos vazios - diz o Coélet -, tudo é vazio." 39 Com Deus, a criação é um canto de louvor ao Criador, sem Deus ela é a imagem do cansaço. "As alegrias da vida são uma via ou uma espécie de revelação de Deus ao homem."40

Em Provérbios, a Sabedoria toma o jovem pela mão e o conduz por um caminho de luz. No Eclesiastes, o sábio conduz o leitor por um caminho de trevas - angústia, pessimismo, indiferença - ao fim do qual vai descobrir que sabedoria é temer a Deus. Enfim, um encontro com o absoluto.

Quanto à Cecília Meireles, vimos que a temática central de sua poesia é a consciência da fugacidade do tempo e nostalgia da eternidade, do que derivam os temas da melancolia, da renúncia, do adeus, da indiferença, do silêncio e da solidão. Encanta-se ela com a beleza da criação e se desespera com a transitoriedade de tudo, temática que repercute a do Eclesiastes.

\footnotetext{
${ }^{38}$ Cf. STEINMANN, J. Ainsi parlait Qohelet, p. 56.

${ }^{39}$ A Bíblia de Jerusalém usa a expressão "vaidade".

${ }^{40}$ Antonio Bonora apud RAVASI, G. Coélet, p. 99.
} 
Na sua lírica, há muitos pontos em comum com o Eclesiastes: a indiferença e a angústia face ao transitório, a consciência do constante "desfazer" das coisas terrenas e a busca incessante pelo absoluto, a aspiração à espiritualidade, ao que é perene, ao que não se desfaz. Lembremos que em "Motivo", ela revela suas "motivações" para criar: "A canção é tudo. / Tem sangue eterno a asa ritmada." Ao se identificar com as fases da lua, em "Lua Adversa", como não nos lembrarmos do Eclesiastes 3,1-15, quando Cecília clama "Fases que vão e vêm / no secreto calendário / que um astrólogo arbitrário / inventou para meu uso."?

No " $4^{\circ}$ Motivo da Rosa", por meio da estruturação em dois em dois versos que encerram, cada um, uma realidade ao mesmo tempo paradoxal e complementar, se articula a temática da brevidade da vida e do tempo que passa inexoravelmente, com algumas semelhanças com Eclesiastes 3,1-15.

Parece-me que uma boa maneira de concluir a lírica de Cecília, em aproximação com o Eclesiastes, é trazer estes versos que também se encontram em Viagem: "E nessas letras tão pequenas / o universo inteiro perdura / E o tempo suspira na altura / por eternidades serenas".

\section{Referências bibliográficas}

AZEVEDO FILHO, L. A. Poesia e Estilo de Cecília Meireles. Rio de Janeiro: José Olympio, 1970.

BÍBLIA DE JERUSALÉM. São Paulo: Paulus, 2002.

BRITO, M. S. Poesia do Modernismo. Rio de Janeiro: Civilização Brasileira, 1968.

BUEHLMANN, A. "Coélet”. In: RÖMER, T; MACCHI, J.-D.; NIHAN, C. (Orgs). Antigo Testamento: história, escritura e teologia. São Paulo: Loyola, 2010, pp.653-663.

COUTINHO, A. “A Revolução Modernista no Brasil”. In: COUTINHO, A. Introdução à Literatura no Brasil. Rio de Janeiro: Livraria São José, 1959, pp. 265-331.

LIMA, M. L. C. Qohelet. Apostila de aula - Escritos Sapienciais. Dep. Teologia, PUC-Rio, 2016.

MANDEL, Y.; NATAF, G. L'Ecclesiaste. Qohelet, le prédicateur désenchanté. Paris: Berg International, 2011. 
RAVASI, G. Coélet. São Paulo: Paulinas, 1993.

STEINMANN, J. Ainsi parlait Qohelet. Col. Lire la Bible, n. 38. Paris: Cerf, 1973.

VERLAINE, Paul. “Art Poétique”. In: LAGARDE, A.; MICHARD, L. Collection Littéraire XIXe. Siècle. Paris: Bordas, 1962, p. 510.

Maria Cristina da Fonseca Elia

Doutora em Letras Modernas pela Universidade Federal do Rio de Janeiro Rio de Janeiro / RJ - Brasil E-mail: cristina.elia@infolink.com.br

Recebido em: 29/08/17 Aprovado em: 27/11/17 